\title{
Analysis on the New Drives of Deaf Education Development in China
}

\author{
Kesheng Li \\ Special Education School \\ Zhongzhou University \\ Zhengzhou, China
}

\begin{abstract}
Recently more and more attention has been focused on the special education group, with the nation's increasing investment and promoting research in special education. In this process, the deaf education grows much more rapidly, and both the old schools and the new groups have their own advantages in the development of deaf education. Combing lots of rich experience from old experts and many new ideas of young teachers in one of the most famous deaf education elite colleges - Zhongzhou University, the author proposes "three driving forces"-optimizing educational process, strengthening education services, and introducing Cloud technology to educational resources, as well as "three education systems" which are fruitful teaching achievements, plentiful teaching methods and rich teaching process, to contribute more to the development of deaf education.
\end{abstract} rich

Keywords-deaf education; three drive; three points; three-

\section{INTRODUCTION}

Since 1999, the higher education completion rate has been rising steadily in China, and it has also promoted the development of higher education of the disabled; the higher vocational education aims at vocational education and training of applied talents, which is a main way to foster the production skills of the disabled, meeting the urgent needs of the disabled for higher education.

\section{RAPID DEVELOPMENT OF HIGHER EDUCATION SCALE FOR THE DISABLED}

The scale and standardization of higher education of the disabled started in the 1980s across China, Changchun University set up a Special Education \& Teaching Department to recruit students who had hearing disability and visual disability to major in decorative advertisement design and traditional Chinese medical massage, which opened a page of the higher education for the disabled in Chinese history after China's reform and opening, afterward, special education colleges or departments (majors) for the disabled were set up in colleges in some provinces and cities, with the spreading of higher education across the country at the end of the last century and the beginning of this century, the higher education of the disabled has been the quickest part developing in the education of the disabled. [1]

\section{ON THE DEVELOPMENT GUIDE FOR THE DEAF EDUCATION}

The disabled is a special group in the society, and the physical disability has brought them a lot of inconvenience, they are also a group in difficulty, of whom, the deaf suffers from loosing hearing, partial or complete hearing failure due to congenital genetic or postnatal illness and drug allergies and so on. Due to the hearing loosing and failure to receive the outside language information via hearing organs, they often loose the optimal stage to learn the vocal language and the improvement in the cognitive stage. The subsequent study and progress will produce adverse consequences chain like butterfly effect. So traditionally, the educational contents for different stages set for the deaf are all aiming at filling the adverse consequences and possible shortage, in the background of the higher education development in modern society, the patterns and contents have taken on a guiding change in the early special education slowly, and more attentions are paid to the characteristics of the deaf their own especially to the characteristics more conspicuous than common people.

One of the major purposes of higher education of the deaf is to improve the sociality, teach knowledge of life and work skills of the deaf, based on which, the author thinks that as far as the higher education stage for the deaf, the guiding orientation for education is divided into two parts: first, filling education, second, disinterring education. The filling education focuses on how to lower the repulsion to the deaf and reduce the inapplicability of their own as possible as they can before the deaf enters the society, and the key part in education is how to shorten the daily distance between the deaf and common people, and how to fill the defect that the deaf is unable to achieve in living and work, for example, inosculating education is a typical filling education, if the deaf listens to the class together with common people, they have to follow teachers' thoughts and classmates' steps in a extremely low efficiency, more time and labor are wasted, even the deaf sigh with emotion like common students: "Are what we learn in class practical?" As for the disinterring education, the deaf is not a single person with defect, there are numerous people who are strong even they are disabled, from Helen Keller, an American writer, instructor and charitarian but loosing hearing after her birth to Zhou Tingting, a Chinese enjoying the honor like "Helen 
Keller"; from Beethoven to Edison, whether before birth or after birth it seems that even they lose hearing but they are compensated with other skills. The disinterring education starts with the advantages of the deaf, special courses and specialties are set with all links are optimized for the higher education so that the potentials of the deaf are exerted to the maximum as the teaching purpose.

The disinterring education has been called during the course of higher education development in China, taking all the people as the base, the higher education still belongs to elite-oriented education but not general education, therefore with resources available, the education aims to instruct students and foster talented people as the final target. The author thinks that the development orientation of the deaf education should follow the "Five-finger principle", everyone has five fingers on one hand, if the short fingers are removed, three will be left; if long fingers are taken, only one will be left. Considering social environment and national conditions, no doubt that the two orientations should be taken together for better effect, more will be discussed on the disinterring education in the paper

\section{Analysis on New Drives of the Deaf EdUCATION BASED ON THE DISINTERRING EDUCATION}

Supposedly take the target of the disinterring education as a short-term task for attempt, considering the teaching study and reform plans of Special Education College of Zhongzhou University, the author suggests making adjustment on multiple links in the deaf education.

\section{A. Three Drives}

Thousands year ago, educators had started researches on the education and presented the core education motto "Teach students in accordance of their aptitude", nowadays, the higher education system has been improved comparatively, which are under steady reform and development. However, due to the short development period, distinct areas, and the education ways varying with different students as well as few students but more strict on instructors than common teachers, all of these have lowered the development of the special education.

Set up in 2001, the Special Education College of Zhongzhou University has about 700 students, of whom, $80 \%$ are the deaf, in many years, from initial finger language interpretation to later special education, art design, phototaking, multimedia and so on, it has accumulated lots of rare experience in the higher education of the deaf and contributed a lot to the deaf education career in China. The author presents three new drives for the special education development based on the "inosculating education" in the college and modern education theories. [2]

1) Optimization of education course. The optimization of education course is a crossed area between the theory and practice to be discussed necessarily in the teaching reform, the so called crossed area means that the education course includes not only teaching and learning, but also practice and question, the motive of the optimization of education that the authors presents includes two parts: 1. During the deaf education, there are some difficulties, speed and particular flexibility changes during the course of teaching and learning, additionally more attention should be paid to practice and question. Before entering the college, the students of the deaf education are different from common ones, teachers are required to know about the students' conditions and adjust the knowledge difficulty in teaching, if the knowledge to be taught necessary to the deaf are hard to memorize for the deaf, the teaching schedule shall be slowed, and the knowledge hard to understand and the practice skills hard to master shall be interpreted in details via demo. 2. Except the teaching and learning, practice and question, the author suggests instructing the students in self learning, namely to increase the "Question and question" course. Considering the conditions of the deaf, during the teaching and instruction teachers deliver information that the deaf may more or less have differences in understanding, and the students may have different understanding to the same objects due to the knowledge accumulation, skills and so on. The so called "Question and question" means students should communicate and help with each other the questions arising out of the learning and practice during the learning, and foster the capabilities to independently discover and solve problems with the teachers' instruction. As such, the teachers may obtain feedback of knowledge from students, and correct in time the difference due to the finger language transfer, observe the students' quality via the communication so as to discover the strong points of students. In the meanwhile, some technical ways may be adopted to achieve the communication via the network and system, and the network platform can be used to record the communication course and contents and save as important teaching and practice data, which can be references for the next students of the specialty and for teachers in teaching reform.

2)Teaching resource cloud storage. During the teaching, question and answer are important drives for progress, so does the deaf education, however, due to the limits in many aspects, the teachers for the deaf education all cannot adopt finger language for teaching, and the finger language interpreters have to interpret in class, during the questioning and answering, complex information will be transferred to the deaf who are unwilling to question for knowledge acquaintance, only feeling shy to communicate with teachers who know nothing about the finger language, in addition, the teachers who know nothing about the finger language in class may neglect whether the interpreter can understand and correctly express the specialty course, and it is possible that the deaf may fail to understand the interpreter's finger language, if so, the deaf may be unwilling to communicate with or question the teachers or the interpreter.

During the teaching research, the author finds that with the scientific development, and spread of network, software and hardware equipment, the information transfer and saving start to turn to the network platform in most cases, and there will be no barriers for the deaf in the area. Accordingly the application of mobile equipment and network by the deaf is not less than common people, with the network development, the information transfer and exchange form via the network differ with the actual society, where the deaf is not rejected, 
who will feel better to receive indifferent information in the network compared to the actual society. After the deaf finds and makes use of the network, the frequency of network application will be higher than that of common people, based on the theory of "Practices makes perfect", the deaf will be much skilled in the operation of mobile equipment and network, meanwhile, due to the demand for exchange, the identification by the deaf on common information and transmission will be more frequent, no doubt the technical factor application in the deaf education will be an optimal selection. During the teaching, the author attempts to make use of the cloud storage in the network platform as teaching resource and guide the deaf to attempt and use the cloud technique; When reading the knowledge information released by teachers on the cloud platform, the deaf has improved the network operation skills, the existing network service platform is used for online teaching attempt, for example, the author creates a Weixin pubic subscription number as the teaching show platform where the teaching contents, documents, effect, skills, hard and easy points, homework and instruction are released, which are pushed regularly to the students for reading and exchange; In addition, the author creates a teaching blog on the public information exchange platform Google + , and releases teaching resources and information via the cloud storage, with the information exchange platform, teachers can communicate with students in real time, keep the communication records, and the question and answer can be shared to special groups, and discussion and communication can be achieved among students via the teaching blogs, both teachers and students may look the communication records, and all the records can be important data for students' improvement and teachers' teaching research.

3) Strengthening of teaching affair. Teaching affair stated herein is narrowed relatively, and it refers to the assistance and administrative affair related to the deaf education, generally whether the teaching assistance or administration in colleges is covered by the "Teaching practice", a good new is that in recent years, during the teaching reform, teaching assistance has been strengthened in colleges to fully support the "Teaching practice", and the administration is taken as the diplomat for the "Teaching practice" for environmental optimization and resource gathering.

a) Teaching affair: Teaching affair refers to the activity related to teaching work, generally it includes teaching preparation by teachers, class teaching, question solving, homework arrangement, reading and review, tests and students' class learning, practice, homework, tests, course arrangement, course organization, textbook review, teachers' research after class, teaching communication and so on. Generally, these are normal teaching affairs, but the deaf of the deaf education has to be strengthened in all aspects of teaching to solve difficulties students may meet in learning, and achieve the innovation of teaching methods and contents at any time to realize the education goal such as the adjustment and innovation of specialties and courses, reasons for the adjustment are to consider the data of teaching affairs accumulated in each term which in some degree may reflect the satisfaction and expectation of students to the specialties and courses, it is unavoidable that the specialty setting may be overlapped and the course setting may be dull and so on, all the information shall be collected in time for review and adjustment by experts. The innovation refers to combination with social events, a college is the first station for the young people to enter the society and a projection of some social practice, and it is extremely necessary to reflect social information and policies in class.

b) Teaching assistance: Teaching affairs herein emphasizes experiment, training and practices arranged for the deaf, and adjusts students' course and specialties setting according to social events and job situation so as to foster the deaf necessary employment skills and learning capability for self development before entering the society. Generally teaching assistances in colleges are arranged with a class or specialty as the unit, due to some limits, the deaf may request increase in a geometric series even request assistance individually, as such the teaching assistance tasks can be achieved with the premise of safety and realize the study goal of class knowledge practice and improving self skills.

c) Administrative affair: The strengthening of administrative affair is often weakened during the construction of colleges, and the administrative affair is often taken as an affiliate to the teaching work. Guided by the top consciousness of "Serve the grassroots", the advantages can be shown after strengthening of the administrative affair, which reflects the full and deep support to the teaching practice by the administrative affairs, meanwhile, if the college is taken as a unit for a teaching group, the strengthening or weakening of administrative affairs may directly influence the college's capability to obtain resources in the teaching group. Take Henan as an example, half or more teaching resources in Henan are invested to Zhengzhou University, one of the reasons is that Zhengzhou University has higher administrative level and stronger administrative affair capability. With full resources, the university as a unit can well run internal teaching affairs and produces more teaching achievements and research results. Meanwhile, the administrative affairs in the teaching agency have public affair attribution and obtain administrative attribution when communicating with above authorities or other units at the same level. The public affair attribution requires it should serve the unit, the society and the education, the administrative attribution requires it should follow the above authority, govern the lower departments and serve the people. The complicated orientation often leads to no achievements even after hard work in the administrative affair, which has to be considered for the deaf education so as to avoid as possible as it can the production or derivation of adverse results.

\section{B. Three-rich Education System}

As an important part in the education career, the deaf education all need corresponding goals to established as the orientation for education fostering and development, considering the past achievements, layout of existing leaders and experts in Zhongzhou University, the author presents a "Rich teaching achievement, rich teaching ways and rich teaching course" teaching system. 
1)Rich teaching achievements. Rich means plentiful and more, the more and better teaching results, how to define the quantity and quality is a key point. During the current university system reform, the title for teachers' promotion is gradually increased and strengthened, in order to meet the requirements and get quick promotion, some who are eager for quick success and instant benefit start to lie in achievement which cause adverse results and become a negative image for correcting improper science and lying. Workers for the deaf education should own more excellent world outlook and values as well as stronger psychology and skill level than common teachers. The so called rich teaching achievement refers not to the higher science theme completed, advanced academic paper released or works on any publications by individuals or other quantizing indices but to the fact where a group engaging in the deaf education can achieve the description of complicated teaching tasks, continue the description of single affairs for a long time and improvement of skills in affair treatment, face together the influence of external environment to the deaf education and treat actively for positive effect, and gather wisdom and improve the level of its own in order for the common goal of the deaf education group.

The academic bound of an expert is limited, however, if the young generation is assisted and instructed in the limited capability on scientific research and teaching, the growth of the deaf education group will be far more the total of the single growth of an individual, meanwhile, based on the fairness principle of "distribution according to work", the experts who offer assistance and instruction should get corresponding achievement encouragement. The deaf education has a short development period in China, and there are few people who would devote themselves to the deaf education, of course the people are treasures for the education field and the deaf field, in teaching field, their teaching results are rich, the key problem is how to create a talent database to gather more talented people like them, the author thinks that the key point depends on interest. Whether in daily teaching, class practice, experiment, training, student management and so on, the deaf education is much more complicated than the general higher education, there are both challenges and opportunities, and there are more increasing points for research in the relatively weak deaf education, and it is possible to create more achievements. To find the interesting point for teachers in the teaching, experiment and training in the deaf education is on the way for sustainable development, in order to make it easy for teachers to find the interesting points of their own, all links in the deaf education shall be analyzed and recorded like works collected in the museum.

2)Rich teaching ways. The author initially used abundant but changes it to rich for correctness. The richness refers to difference and applicability. Teaching ways mean ways used to achieve certain teaching goals, obviously the teaching ways may vary with the people. Teaching goal refers to the final effect that teaching activities described in teaching outline, check requirements and so on aim to achieve, yet the effect varies with the time, in the quality education time, the effect means that students are willing to obtain more knowledge, and the current professional education time just makes students master employment skills negatively. What the effect will be, with the teaching contents changed, the teaching ways may change or go as usual. Accordingly the teaching ways just face single problems as "good appearance, meaningful, useful" but hard to achieve.

Teachers in the Special Education College of Zhongzhou University combine skills and teaching experience of their own have researched and created "Inosculate teaching", "Project teaching" "Workroom teaching" and so on, which are rich and applicable.

3) Rich teaching course. Rich here means abundant like light rain and running river. Teaching course and teaching ways may have contents overlapped, the paper here emphasizes the differences, which include the difference in receiving the same teaching course between the deaf and common students, the difference in receiving different course teaching between the deaf, and the difference in practice, experiment, training and design of the deaf after receiving the same demo.

As for the higher education, whether previous quality education or current professional education both take the students' capability as the major goal for fostering, In the capability fostering, the self teaching capability will be the basic capability to be fostered for guiding, and the students in colleges will have no spoon-fed pressure, but they will have thirst for facing problems independently due to changes in age and psychology, so do the deaf. Starting from the day of entering the college, it has been cleared that the students' study, work and living will depend on the self teaching capability of their own.

After leaving parents, teachers' care and helps in middle schools, new living environment, new partners, new study and life styles have brought tem horrors and happiness, and it will be much more complicated to guide the deaf than common students, most guide and influence to the deaf will be done in teaching, therefore, it is extremely necessary to keep long time teaching, strict guide and full contents.

In a word, the development is an absolute principle, both education and science are developing without stop, the drive for the development of the deaf education not only comes from the instruction of workers and experts and scholars but also the insistence in the deaf education, it is said that slowness is better than stop, all of us should find new development drives continuously on the way to the deaf education development and struggle for the future.

Thanks to: the paper initially got its title "Analysis on the Core Competitive Forces of the Deaf Education Development in China", later, after considering "Special education is a charity career and I feed honored for my devotion to the special education" (reported) said by pro Meng Fanling, president of Special Education College of Zhongzhou University, the groups of charity career shall be not competitors, even the results will promote the career development, maybe, the cooperation will make it better, so it gets its current name "Analysis on the New Driving Forces of Deaf Education Development in China". 


\section{REFERENCES}

[1] Liang Hui, Qu Xueli, Study on the Talented People Fostering for the Higher Education of the Disabled, Chinese Professional Education, $2010(31)$

[2] http://www.zhzhu.edu.cn/lryssjxy/article_view.asp?id=223 